\title{
PROBLEMATIKA DALAM PENERAPAN HUKUM WARIS ISLAM
}

\author{
Andi Tenri Leleang ${ }^{1} \&$ Asni Zubair ${ }^{2}$ \\ Mahasiswa dan Dosen Fakultas Syariah dan Hukum Islam \\ Institut Agama Islam Negeri (IAIN) Bone \\ Jl. Hos Cokroaminoto, Watampone, Kab. Bone, Indonesia \\ Email: ${ }^{1}$ anditenrileleang16@gmail.com; dan ${ }^{2}$ annibintizubair@gmail.com
}

\begin{abstract}
This study aims to determine the implementation and constraints that affect the application of Islamic inheritance law. This research is a field research, using descriptive, sociology, normative theology, historicalapproach, and presented qualitatively. The result shows that the implementation of Islamic inheritance law is carried out in kinshipprinciple. Special sections are provided for the heirs who take care of their parents and thepurabage inheritance as absolute power. The application of the law to the distribution of assets is done by dividing the heirs in kinship principle without seeing the provisions of God's law. Problems in the application of Islamic inheritance law include the customary law and poor understanding of Islamic inheritance law.
\end{abstract}

Keywords: Problems, Application, Islamic Inheritance Law.

\begin{abstract}
:
Kajian ini bertujuan untuk mengetahui implementasi dan kendala yang mempengaruhi penerapan hukum waris Islam. Penelitian ini merupakan penelitian lapangan, menggunakan metode pendekatan deskriptif, sosiologi, teologi normatif, historis, dan disajikan secara kualitatif. Penelitian menunjukkan bahwa implementasi hukum waris Islam dilakukan secara kekeluargaan. Bahagian khusus yang disediakan untuk ahli waris yang memeilihara orang tuanya dan harta waris pura bage sebagai kekuasaan mutlak. Penerapan hukumnya untuk pembagian harta kalālah dilakukan dengan membagi kepada ahli waris secara kekeluargaan tanpa melihat ketentuan hukum Allah. Problematika dalam penerapan hukum waris Islam di antaranya kentalnya hukum adat dan rendahnya pemahaman hukum waris Islam.
\end{abstract}

Kata Kunci: Problematika, Penerapan, Hukum Waris Islam. 


\section{PENDAHULUAN}

Alquran dan sunnah merupakan firman Allah swt. yang di dalamnya terkandung banyak pelajaran dan sekaligus penyempurna kitab-kitab sebelumnya. Di sampan itu Alquran sebagai pedoma hidup bagi umat Islam. Mengamalkan ajaran Alquran, hendaknya memahami terlebih dahulu ketentuan-ketentuan dalam hukum Islam. Hukum Islam yang dimaksud adalah peraturan yang diciptakan Allah swt. supaya manusia berpegang teguh kepadanya. Ajaran yang dibawa oleh Nabi, baik hukum yang berhubungan dengan kepercayaan (aqidah) maupun hukum-hukum yang berhubungan dengan perbuatan (amaliyah). Selain itu, maksud lain tujuan hukum Islam adalah untuk menciptakan rasa keadilan di antara umat Islam itu sendiri. ${ }^{1}$

Tujuan hukum berdasarkan hukum Islam bila ditelaah sebenarnya sama dengan maksud tujuan hukum yang dikemukakan L.J. van Apeldoorn. Menurutnya, hukum bertujuan untuk mengatur pergaulan hidup secara damai. Pendapat lain mengatakan, tujuan hukum adalah sebagai sesuatu yang menciptakan manfaat sebanyak-banyaknya dan memberikan kepastian hukum pada pihak yang satu dengan pihak lain. ${ }^{2}$ Pada dasarnya manusia mengalami tiga tahap kehidupan yakni lahir, hidup, dan mati. Semua tahap itu membawa pengaruh dan akibat hukum kepada lingkungannya, terutama dengan orang yang dekat dengannya. Baik dekat dalam arti nasab maupun dalam arti lingkungan. ${ }^{3}$

Peristiwa kematian mengakibatkan timbulnya cabang ilmu hukum yang dalam Syariat Islam, ilmu tersebut dikenal dengan nama Ilmu Mawaris, Fikih Mawaris, atau Farāiḍ. Hukum waris adalah hukum yang mengatur peralihan harta orang yang meninggal kepada yang ditinggalkan berbentuk hak dan kewajiban. Menurut Sayyid Sābiq mendefinisikan farāiḍ adalah bentuk jamak dari farị̣ah yang diambil dari kata farḍ yang artinya takdir (ketentuan), dalam istilah syarak

\footnotetext{
${ }^{1}$ Abdur Rahman I. Doi, Syariah The Islamic Law Terj.Zaimuddin dan Rusydi Sulaiman, Hudud dan Kewarisan [Syariah II] (Cet. I; Jakarta: RajaGrafindo Persada, 1996), h. 1.

${ }^{2}$ Seperti dikutip oleh Ahmad Tholabi Kharlie, Hukum Keluarga Islam (Cet. I; Jakarta Timur: SinarGrafika, 2013), h. 59-60.

${ }^{3}$ Suhrawardi K Lubis dan Komis Simanjutak, Hukum Waris Islam [Lengkap dan Praktis] (Cet. I; Jakarta: Sinar Grafika, 1995), h. 1.
} 
farḍ adalah bagian yang telah ditentukan bagi ahli waris. Kemudian Muḥammad 'Ali aṣ-Șabūni memberikan makna waris menurut istilah yakni berpindahnya hak kepemilikan dari seseorang yang meninggal kepada ahli warisnya yang masih hidup, baik yang ditinggalkan itu berupa harta (uang), tanah atau berupa hak milik secara Syar'i. ${ }^{4}$

Pada dasarnya hukum waris berkaitan dengan berakhirnya harta kekayaan/kepemilikan seseorang disaat meninggal dunia kepada ahli warisnya secara ijbāri (otomatis). Adapun ruang lingkupnya menyangkut masalah pengurusan/penyelesaian harta peninggalan meliputi kelanjutan hak-hak dan kewajiban-kewajiban si mayit kepada ahli waris yang ditinggalkan. Penyelesaian harta peninggalan tersebut ditentukanlah siapa-siapa yang menjadi ahli waris, siapa-siapa yang berhak mendapatkan bagian harta warisan tersebut, berapa bagian mereka masing-masing, bagaimana ketentuan pembagiannya serta diatur pula berbagai hal yang berhubungan dengan pembagian harta warisan. ${ }^{5}$

Dewasa ini, penerapan hukum kewarisan Islam berjalan tidak sesuai dengan aturan yang telah ditentukan Allah dalam nashnya (Alquran dan Sunnah). Hal ini karena banyaknya problematika atau alasan yang menyebabkan terjadi demikian. Salah satu alasannya adalah karena manusia tidak menganggap penting ilmu waris itu dan akhirnya akan terlupakan ilmunya, sebagaimana hadis yang mengatakan:

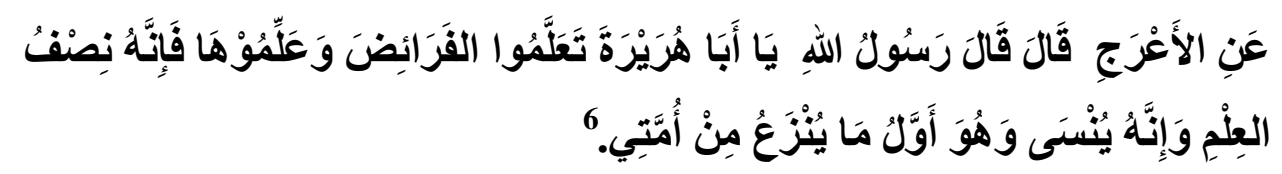

Terjemahnya:

Dari A’raj raḍiyallahuanhu bahwa Rasulullahi saw. bersabda,"Wahai Abu Hurairah, Pelajarilah ilmu farāid dan ajarkanlah. Karena dia setengah dari ilmu dan dilupakan orang. Dan dia adalah yang pertama kali akan dicabut dari umatku. (H.R. Ibnu Majah dan Daraqutni)

${ }^{4}$ Seperti dikutip oleh Syamsulbahri Salihima, Perkembangan Pemikiran Pembagian Warisan dalm Hukum Islam dan Implementasinya pada Pengadilan Agama (Cet. I; Jakarta: Kencana, 2015), h. 27.

${ }^{5}$ Otje Salman S, Hukum Waris Islam (Cet. III; Bandung: Refika Aditama, 2010), h.1.

${ }^{6}$ Abi' Abdillāh Ibnu Mājah, "Sunan Ibnu Mājah" (Cet.II; Beirūt: DĀR al-Kutub al'Ilmiyyah, Jilid III, 2009), h. 322. 
Berdasarkan hadis, tampak jelas bahwa kenyataan hadis tersebut terjadi sekarang ini. Urgensi hukum kewarisan Islam untuk diketahui oleh umat Islam sebagai bentuk ketaatan kepada Allah dan Rasulnya tidak diindahkan dalam pelaksananya. Hukum waris Islam diatur dengan bentuk yang sangat teratur, hal ini dapat dilihat sebagaimana dikatakan dalam firman Allah swt. QS. anNisā/4:13-14:

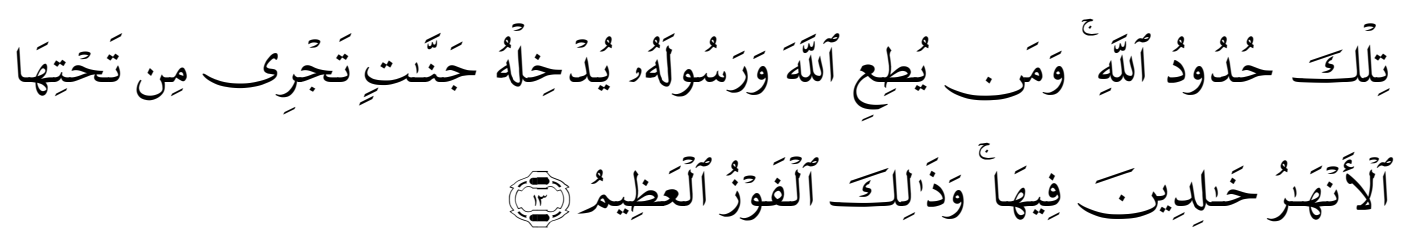

Terjemahnya:

Itulah batas-batas (hukum) Allah. Barangsiapa taat kepada Allah dan RasulNya, Dia akan memasukkannya ke dalam surga yang mengalir di bawahnya sungai-sungai, mereka kekal didalamnya. Dan Itulah kemenangan yang agung. ${ }^{7}$

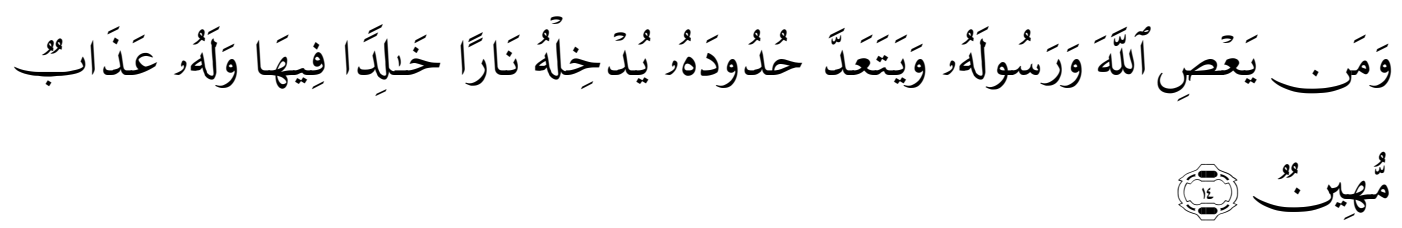

Terjemahnya:

Dan barang siapa yang mendurhakai Allah dan Rasulnya dan melanggar batas-batas hukumnya, niscaya Allah memasukkannya ke dalam api neraka, dia kekal di dalamnya dan dia akan mendapat azab yang menghinakan. ${ }^{8}$

Penjelasan an-Nisa/4:13-14 dapat dipahami bahwa penerapan hukum kewarisan Islam benar-benar harus dilakukan sesuai aturan. Signifikansi ilmu farāid memerlukan suatu pengetahuan khusus tentang perhitungan. Untuk bisa benar-benar memahaminya, dampaknya juga telah Allah swt. janjikan ganjaran surga dan neraka bagi pelaksananya. Selain Alquran dan Sunnah, untuk memudahkan penyelesaian pembagian harta warisan, pemerintah mengeluarkan

${ }^{7}$ Departemen Agama RI, Alquran dan Tafsirnya (Cet. III; Jakarta: Lembaga Percetekan Alquran Departemen Agama, 2009), h. 120.

${ }^{8}$ Departemen Agama RI, Alquran dan Tafsirnya, h. 121.

${ }^{9}$ Amin Husein Nasution, Hukum Kewarisan [Suatu Analisis Komparatif Pemikiran Mujtahid dan Kompilasi Hukum Islam] (Cet. III; Jakarta: RajaGrafindo Persada, 2014), h.33-39. 
aturan dalam bentuk Instruksi Presiden Nomor 1 tahun 1991 yakni Kompilasi Hukum Islam terjabarkan dalam Pasal 176 sampai dengan Pasal 183. ${ }^{9}$

Berkaitan dengan latar belakang yang telah diuraikan, maka sangat menarik untuk dikaji lebih lanjut tentang problematika dalam penerapan hukum waris Islam. Untuk lebih mendalamnya kajian ini, maka sub permasalahan yang dijadikan objek pembahasan adalah, bagaimana penerapan hukum waris Islam di masyarakat dan kendala apa yang menjadi faktor penghambat penerapan hukum waris Islam di masyarakat.

\section{PEMBAHASAN}

Hukum waris dalam ajaran Islam disebut dengan istilah "Farāiḍ". Para ulama fikih memberikan definisi ilmu Farāiḍ yakni; (1) Penentuan bagian bagi ahli waris; (2) Ketentuan bagian warisan yang ditetapkan oleh syariat Islam; (3) Ilmu fikih yang berkaitan dengan pembagian pusaka, serta mengetahui perhitungan dan kadar harta pusaka yang wajib dimiliki oleh orang berhak. ${ }^{10}$ Maka yang dimaksud hukum waris Islam adalah berpindahnya hak kepemilikan dari seseorang yang meninggal dunia kepada ahli warisnya yang berhak dan telah ditetapkan pula kadar jumlahnya baik berupa harta (uang), atau tanah atau apa saja yang berupa hak milik secara Syar'i.

Sejarah yang telah terjadi menjelaskan bahwa masalah hukum waris khususnya hukum waris Islam mengalami proses yang begitu panjang dan rumit. Hal ini dibuktikan dengan pewarisan yang terjadi di masa pra Islam adalah berdasarkan tradisi dan adat kebiasaan bangsa Arab zaman jahiliyah. Ada tiga penyebab peralihan harta warisan yakni; pertama, disebabkan garis keturunan atau hubungan nasab atau kekerabatan. Kedua, melalui jalur pengangkatan anak atau adopsi. Ketiga, melalui sebuah perjanjian.

Perkembangan hukum kewarisan pada awal Islam sampai dengan sekarang dihadirkan secara bertahap (tadarruj) agar hukum kewarisan Islam dapat mudah diterima oleh masyarakat yang sudah mapan dengan sistem dan tradisi

\footnotetext{
${ }^{10}$ Moh. Muhibbin dan Wahid, Hukum Kewarisan Islam (Sebagai Pembaruan Hukum Positif di Indonesia) (Cet.II; Jakarta: Sinar Grafika, 2011), h. 7.
} 
kewarisan leluhurnya. Sebab-sebab yang memungkinkan seseorang memperoleh harta warisan pada masa awal Islam, yakni:

(a) Pertalian garis keturunan atau hubungan nasab atau kekerabatan

Dan sekarang, terkait hal ini sebagai sebab seorang memperoleh harta warisan tidak terbatas pada kaum laki-laki dewasa saja tetapi juga untuk kaum perempuan dan anak-anak.

(b) Pengangkatan anak (al-tabanni) atau adopsi;

Sekarang, pengangkatan anak beserta akibatnya hukum berakhir setelah turun QS al-Aḥzāb/33:4-5.

(c) Hijrah dari Mekkah ke Madinah;

(d) Ikatan persaudaraan (al-mua khah) antara Muhajirin dan Ansar.

Adapun Hijrah dari Mekkah ke Madinah dan persaudaraan kaum Muhajirin dengan kaum Anshor sebagai salah satu sebab mewarisi telah di nasakh oleh firman Allah dalam surah QS al-Aḥzāb/33:6.

Maka setelah mengalami proses yang panjang, sebab yang menjadikan umat Islam saling mewarisi adalah berdasarkan garis nasab atau keturunan dan perkawinan yang sah. Untuk mendapatkan jawaban dari masalah problematika dalam penerapan hukum waris Islam, dibutuhkan penganalisaan terkait bagaimana penerapan juga kendala yang mempengaruhi penerapan hukum waris Islam.

\section{Penerapan Hukum Waris Islam Bagi Anak}

Penerapan hukum waris Islam terkait anak yang terjadi di masyarakat dilakukan sebagai berikut;

(a) Pembagian harta warisan untuk anak dilakukan secara kekeluargaan

Hukum kewarisan tidak dapat dipisahkan dari sistem kekeluargaan sebab hukum kewarisan merupakan bagian dari hukum kekeluargaan. Hukum adat sebagai yang pertama sistem hukum yang dikenal, berasal dari tradisi atau kebiasaan masyarakat suatu daerah sehingga membuatnya memiliki posisi yang penting dalam mengatur kehidupan masyarakat. ${ }^{11}$ Sebagaimana dalam hasil wawancara narasumber bahwa:

\footnotetext{
${ }^{11}$ Ahmad Azhar Basyir, Hukum Waris Islam Edisi Revisi (Cet. XIV; Yogyakarta: UII Press Yogyakarta, 2001), 143.
} 
Pembagian warisan hampir seluruh wilayah di Indonesia semua menerapkan pembagian harta waris secara kekeluargaan. Yang membedakannya hanyalah bagaimana menafsirkan kekeluargaan ini untuk mewujudkan keadilan dalam suatu keluarga. ${ }^{12}$

Konsep kekeluargaan ini mengandung dua penafsiran. Pertama, pembagian harta warisan secara kekeluargaan dilakukan demi terwujudnya prinsip keluarga adalah segalanya. Maksudnya para ahli waris harus menerima pembagian harta itu baik tahu atau tidak tahu, hukumnya sepakat dilakukan sesuai ketetapan orang tua ataupun kakak tertua. Kedua, Pembagian harta warisan secara kekeluargaan dilakukan dengan berusaha musyawarah, berdiskusi dengan baik demi mecapai mufakat, namun tetap memperhatikan kadar bagian setiap ahli waris yang telah menjadi ketetapan Allah. Misalnya kadar yang ditetapkan Allah terhadap anak 2:1 (satu laki-laki mendapat dua bagian perempuan) berusaha adil dalam menerapkannya.

(b) Bagian khusus disediakan ahli waris yang memelihara orang tuanya

Hasil penelitian yang dilakukan di Kecamatan Mare Kabupaten Bone, empat dari sepuluh keluarga di masyarakat dalam pembagian harta waris anak melakukan tindakan yakni harta berupa rumah sebagai aset penting dan tempat tinggal orang tua akan diserahkan kepada anak perempuan yang belum menikah dan hidupnya hanya habis untuk mengurusi orang tuanya. Hal ini dilakukan dengan maksud sebagai bekal anak perempuan bila ditinggalkan si mayit dan solusi atas pelepasan tanggung jawab saudara laki-lakinya bila orang tuanya meninggal dunia. Karena seperti diketahui bila dalam keluarga besar telah meninggal kedua orang tua maka saudara laki-laki bertanggung jawab atas saudara perempuannya yang belum menikah. ${ }^{13}$ Posisi saudara laki-laki menggantikan posisi kedua orang tua, sehingga tanggung jawab orang tua akan beralih kepada saudara laki-lakinya, ketetapan itu diamalkan pada masyarakat Kecamatan Mare Kabupaten Bone.

\footnotetext{
${ }^{12}$ Andi Hikmat Samad Makkuasseng, Kepala Desa Kadai Kecamatan Mare Kabupaten Bone, Wawancara di kantor Desa Kadai Kecamatan Mare Kabupaten Bone, 15 Juli 2019.

${ }^{13}$ Andi Himat Samad Makkuaseng dan Andi Salinri, Kepala Desa Kadai dan Sumaling Kecamatan Mare Kabupaten Bone, Wawancara di kantor Desa Kadai dan Sumaling Kecamatan Mare Kabupaten Bone, 15 Juli 2019.
} 
(c) Harta waris pura bage sebagai kekuasaan mutlak mayit

Harta pura bage adalah pembagian warisan dengan cara pemberian dari orang tua kepada anak sesuai dengan sudut pandangnya untuk menetapkan kadar harta yang diterima anak.

Sebagaimana kajian yang dilakukan di Kecamatan Mare Kabupaten Bone salah satu masyarakat menyampaikan yakni ibu Andi Jamilah, bahwa harta pura bage banyak terjadi di masyarakat. Penyebab utamanya adalah kurangnya ilmu pengetahuan tentang hukum waris Islam juga yang berkaitan dengannya seperti masalah hibah dan wasiat sehingga orang tua mengambil jalan pintas membagi lebih dulu hartanya.

Alasan lainnya, ketakutan terbesar orang tua akan perselisihan sepeninggalnya, sehingga mereka berusaha membagi dengan berdasar pada karakteristik anak dengan seadil mungkin. Penerapannya seperti sudah ditentukan pembagiannya terhadap anak-anaknya.

(d) Pengetahuan ilmu waris Islam dan eksistensi penerapan hukum waris

Setelah melakukan survey dan wawancara di masyarakat Desa Kadai dan Sumaling Kecamatan Mare Kabupaten Bone, lima warga ditemui, empat dari mereka tidak mengetahui ilmu pembagian harta waris. Salah satu jawaban mereka ketika diajukan pertanyaan bagaimana penerapan hukum waris anak, menurut Ibu Rabiati:

Ketika seseorang meninggal di Sumaling, masalah hartanya diselesaikan oleh keluarga tertua. Ahli waris takut ikut campur dalam pembagiannya. Bila mendapat bagian sudah Alhamdulillah. ${ }^{15}$

Jika mendapatkan harta warisan saja sudah Alhamdulillah. Kalau mengikuti jumlah bagian dalam Alquran hanya membuka pintu perselisihan saja, lagi pula kami juga tidak tau bagi-baginya. ${ }^{16}$

Maksud perkataan seorang warga masyarakat bahwa jika pembagian harta waris dilakukan berdasar pada ketentuan Allah dalam Alquran akan

\footnotetext{
${ }^{14}$ Andi Jamilah, Masyarakat Desa Sumaling Kecamatan Mare Kabupaten Bone, Wawancara dilakukan di depan rumah, 15 Juli 2019.

${ }^{15}$ Rabiati, Masyarakat Desa Sumaling Kecamatan Mare Kabupaten Bone, Wawancara dilakukan di depan rumahnya, 15 Juli 2019.

${ }^{16}$ Syarifudding, Masyarakat Desa Kadai Kecamatan Mare Kabupaten Bone, Wawancara dilakukan di depan rumahnya , 15 Juli 2019.
} 
membuka pintu perselisihan dalam keluarga. Sebagian besar masyarakat di Desa Kadai mendefinisikan kata adil dengan nilai yang sama, tidak ada kepincangan untuk kedua atau lebih orang. Jika dilihat pembagian Allah yang membedakan 2:1 untuk laki-laki dan perempuan, maka perempuan mendapatkan sedikit sementara tidak ada yang dapat membedakan penciptaan laki-laki dan perempuan. Keduanya memiliki kedudukan yang sama, yang membedakannya adalah ketakwaan.

Masalah pembagian warisan kalālah di Desa Kadai sebenarnya ada satu kasus, namun setelah melakukan usaha untuk mewawancarai pihak keluarga, mereka menolak dengan alasan bahwa pembagian harta saudaraku adalah konsumsi keluarga. Dugaan penulis dari penjelasan tetangga mengatakan:

Seorang yang bernama puang Andi Mini telah wafat dengan meninggalkan harta sebanyak Rp.35.000.000. Karena tidak menikah, semasa hidupnya dia dirawat oleh keponakannya. Keempat saudaranya telah menikah dan memiliki keluarga. Sepeninggalnya, beliau menyimpan wasiat berupa surat yang mengatakan akan memberikan sejumlah uang yakni sebesar Rp.15.000.000 untuk modal kuliah dan usaha sang keponakan. Jika diperhatikan jumlah hibahnya melebihi sepertiga. Kemudian, salah seorang saudaranya juga tidak mengetahui pembagian harta warisan tersebut sama sekali tidak mendapatkan harta. Faktor penyebabnya adalah saudaranya ini tinggal di Jakarta dan memang kurang baik hubungan silaturahminya ${ }^{17}$

Satu kasus lain yang ditemui di Sumaling berkenan untuk diwawancarai mengutarakan bahwa:

Beliau yang meninggal bernama $\mathrm{Hj}$. Andi Bollo. Seorang pensiunan PNS guru agama yang memiliki tujuh saudara, yakni $\mathrm{Hj}$. Andi Djanuati (Pensiunan PNS), Andi Atikah (Pensiunan PNS), Andi Amien Ahmad (Pensiunan PNS), Andi Bahe (PNS Guru SD), Andi Sukawati (Sarjana S1), Andi Nuramang (Sarjana S1) dan Andi Kabir Ahmad (Sarjana S1). Dari ketujuh saudaranya, tiga yang tidak memiliki pekerjaan, mereka adalah Andi Kabir Ahmad, Andi Nuramang dan Andi Sukawati. Dari ketujuh saudaranya pun ada dua yang tidak menikah yakni Andi Djanuati dan Andi Sukawati. ${ }^{18}$

Penjelasan secara konkrit dan rinci terkait dengan harta yang ditinggalkan almarhumah sebagai penjabaran bahwa:

\footnotetext{
${ }^{17}$ Andi Djanuati, Masyarakat Desa Sumaling Kecamatan Mare Kabupaten Bone, Wawancara dilakukan di depan rumahnya, 15 Juli 2019.

${ }^{18}$ Andi Sukawati, Saudara kandung almarhumah, Wawancara dilakukan di rumahnya di Sumaling, 15 Juli 2019.
} 
Deposit sebesar Rp.100.000.000 yang disimpan di Bank Syariah Mandiri. Uang tunai yang ditemukan dalam sarung sejumlah Rp.10.000.000. Harta benda berupa emas dengan rincian; (a) emas stelan (cincin dan anting) seberat 8 gram sebanyak empat stelan yang jika dirupiahkan dengan harga emas 24 karat per gramnya Rp. 600.000 maka senilai Rp.19.200.000; (b) Kalung emas permata seberat 10 gram sebanyak dua buah yang jika dirupiahkan dengan harga emas 24 karat per gramnya Rp.600.000 maka senilai Rp. 12.000.000. Cincin emas biasa seberat 7 gram sebanyak tiga buah jika dirupiahkan dengan harga emas 24 karat per gramnya Rp.600.000 maka senilai Rp.12.600.000. Kalung markis senilai Rp.8.000.000. ${ }^{19}$

Dari kesemua hartanya dapat dijumlahkan ke dalam rupiah sebanyak Rp. 161.800.000 (seratus enam puluh satu juta delapan ratus ribu rupiah). Implentasi harta tersebut dibagikan kepada ketujuh saudaranya, keponakan dari anak saudaranya, dan cucunya.

Deposito Rp.100.000.000 itu dibagi tiga. Kepada Andi Sukawati dan Andi Kabier Ahmad sebanyak masing-masing Rp.25.000.000. Untuk kedua saudaranya diberikan deposit ini dengan alasan Andi Kabier tidak memiliki pekerjaan dan harus menghidupi anak istrinya sedangkan Andi Sukawati tidak memiliki pekerjaan dan belum menikah. Andi Muhammad Fuad sebagai cucu anak dari keponakan saudara perempuannya mendapat Rp.50.000.000 deposit uang si mati. Alasan diberikan banyak karena dia adalah anak asuhnya dan ada janji memberangkatkan cucunya ini umroh. Tambahan, selain deposit Andi Muhammad Fuad juga mendapatkan kalung markis melalui wasiat almarhumah.

Hibah yang telah diucapkan mayit sebelumnya juga ditunaikan dengan memberikan kepada tiga keponakan perempuannya sebuah cincin emas sebagai hadiah perkawinan kelak. Terakhir, sisa hartanya barulah dibagikan kepada ketujuh ahli warisnya. ${ }^{20}$

Penyimpangan yang terjadi adalah; Pertama, meskipun saudara kandungnya semua mendapatkan harta waris namun kadarnya tidak sesuai aturan Islam. Aturannya adalah bila bercampur saudara lebih dari seorang laki-laki dan

${ }^{19}$ Andi Sukawati, Saudara kandung almarhumah, Wawancara dilakukan di rumahnya di Sumaling, 15 Juli 2019.

${ }^{20}$ Andi Djanuati, Saudara kandung almarhumah, Wawancara dilakukan di rumahnya di Sumaling, 15 Juli 2019. 
perempuan maka pembagiannya $2: 1$, artinya satu saudara laki-laki mendapat dua bagian perempuan. Dikatakan bermusyawarah untuk sepakat, namun setelah mewawancarai salah seorang saudaranya ternyata hanya sepakat karena tidak mengetahui ilmunya, keinginan untuk protes tidak ada gunanya. Kedua, Andi Muhammad Fuad dalam aturan Islam bukan merupakan ahli waris yang dapat menerima harta warisan karena terhijab. Mendapatkan melalui wasiat dalam kasus ini kadarnya lebih dari 1/3 harta menunjukan penyimpangan.

Ketentuan Islam seharusnya penyelesaian masalah pembagian harta warisan kasus di atas adalah Pertama, menyelesaikan urusan mayit terlebih dahulu meliputi; penyelenggaraan jenazahnya, hutang yang ditinggalkan mayit, dan wasiat mayit yang harus dipenuhi. Ketiganya harus diperhatikan dan dilaksanakan oleh para ahli waris demi baiknya kematian mayit. Berkaitan dengan wasiat seorang yang mati sepatutnya dilaksanakan bilamana kadarnya tidak boleh lebih dari 1/3 harta yang ditinggalkan jika ahli waris tidak setuju. ${ }^{21}$

Kedua, menentukan para ahli waris dan jumlah harta yang ditinggalkan. Kasus di atas yang menjadi ahli waris adalah ketujuh saudaranya yang miliknya diterima dari hasil dibagi sembilan hartanya. Maksudnya karena meninggalkan empat saudara perempuan maka setiap saudara perempuan ini mendapat satu bagian sedangkan dua saudara laki-laki masing-masing mendapat dua bagian dari harta. Jadi keduanya mendapat empat bagian. Dari segi jumlah harta yang ditinggalkan pada kasus di atas sebanyak Rp. 161.800.000 (seratus enam puluh satu juta delapan ratus ribu rupiah) namun setelah menyelesaikan perkara jenazah, utang dan wasiat maka harta waris yang ditinggalkan adalah Rp.41.200.000.

Penyelesaian pembagian harta yang dilakukan pihak keluarga atas kasus di atas adalah (a) menunaikan wasiat secara tertulis terhadap cucu dengan memberikan sejumlah uang Rp.58.000.000 yang berasal dari deposit Rp.50.0000 dan kalung markis Rp.8.000.000.; (b) menunaikan wasiat lisan mayit sebelum meninggal yakni lebihnya deposit diberikan kepada Andi Kabier dan Andi Sukawati masing-masing Rp.25.000.000; (c) hibah yang diberikan kepada tiga

\footnotetext{
${ }^{21}$ Syamsulbahri Salihima, Perkembangan Pemikiran Pembagian Warisan dalm Hukum Islam dan Implementasinya pada Pengadilan Agama (Cet. I; Jakarta: Kencana, 2015), h.80.
} 
keponakannya yang masing-masing mendapatkan Rp.4.200.000 yang berasal dari cincin emas yang diuangkan; (d) Kepada saudaranya dibagikan harta warisan dari Rp.41.200.000 dengan rincian; Andi Kabier Ahmad mendapat Rp.10.000.000 dengan alasan sebagai modal membangun rumah untuk keluarganya. Andi Djanuati dan Andi Atika masing-masing senilai Rp.7.500.000. Andi Nuramang, Andi Bahe, Andi Sukawati dan Andi Amin Ahmad masing-masing senilai Rp.4.000.000.

Seharusnya jika sesuai dengan ketentuan Allah maka pembagiannya adalah dari ketujuh saudaranya harta dibagi sembilan dengan jumlah lima saudara perempuan mendapatkan masing-masing Rp.4.577.777,- dan kedua saudara lakilakinya masing-masing mendapatkan Rp.9.155.555.-

\section{Faktor Penghambat yang Mempengaruhi Penerapan Hukum Waris Islam}

Penerapan hukum waris Islam pada pembagian harta anak yang terjadi di masyarakat dari hasil penelitian masih sangat kurang penerapan hukum Islamnya. Masyarakat hanya sekedar tahu bahwa membagi harta dengan jumlah bagian lakilaki lebih banyak dibandingkan jumlah perempuan. Pembagian sederhana juga dilakukan dengan membagi harta secara sama kepada seluruh ahli waris. Dapat dipahami bahwa kendala yang mempengaruhi sebagai akibat dari problematika dalam penerapan hukum waris Islam.

(a) Hukum adat yang menguasai pelaksanaan pembagian harta waris

Eksistensi hukum adat yang telah mendarah daging dan berlaku secara turun temurun sebagai kebiasaan masyarakat dalam penerapan hukum waris tidak memberikan ruang bagi perkembangan hukum waris Islam. Hasilnya hampir seluruh penyelesaiannya dilakukan secara kekeluargaan dengan tanpa melibatkan pemerintah sebagai penegak hukum. ${ }^{22}$ Sebagaimana argumentasi masyarakat bahwa:

Karena tidak adanya Undang-Undang terkait waris di Indonesia maka masyarakat sebagian besar mengembalikan penyelesaian pembagian harta waris kepada yang memiliki pengaruh dalam suatu wilayah, yang

\footnotetext{
${ }^{22}$ Otje Salman, Kesadaran Hukum Masyarakat terhadap Hukum Waris (Cet.II; Bandung: PT.Alumni, 2007), h. 91.
} 
dimaksud adalah toko adat. Hal ini disebabkan karena keputusan yang diambil telah diterapkan secara turun temurun. ${ }^{23}$

(b) Sikap dan ilmu pengetahuan yang kurang memadai terkait hukum waris Islam

Kendala kedua yang dihadapi karena tidak terterapkannya hukum waris Islam adalah sikap masyarakat yang kurang peduli atau tidak menganggap penting pelaksanaan hukum waris Islam. Anggapan mereka bahwa selagi penyelesaian harta warisan bisa dilakukan secara kekeluargaan mengapa harus berbelit dengan angka-angka yang secara kasat mata tidak adil sebagai ketentuan Allah. Ilmu pengetahuan tentang hukum waris Islam yang kurang memadai juga menjadi faktor pendukung lemahnya penerapan hukum waris Islam di Desa Kadai dan Desa Sumaling Kecamatan Mare Kabupaten Bone. Dampaknya adalah; (1) menyamakan bagian anak laki-laki dengan perempuan; (2) Tidak mampu membedakan antara Kewarisan, Wasiat dan Hibah sebagai solusi peralihan harta seseorang. $^{24}$

(c) Menjunjung tinggi Perbedaan strata sosial masyarakat

Hukum adat yang mendarah daging dan pengaruh penjajahan di Indonesia telah memberikan sekat dalam masyarakat terkait penerapan hukum kewarisan Islam. ${ }^{25}$ Strata sosial yang dikenal di suku Bugis secara umum terdiri atas tiga klasifikasi yakni, arung (bangsawan) dikenal dengan penambahan kata Andi dalam nama keturunannya, rakyat biasa dan $a t a$ '.

Melaksanakan kehidupan sehari-harinya pun akan sulit bersentuhan ketiga strata sosial tersebut. Yang merasa bangsawan akan melakukan aktifitasnya seolah tahu semua hukum, khususnya hukum waris sehingga tidak akan menerima masukan dan penjelasan dari orang lain, apalagi bila yang memberikan penjelasan itu berasal dari kalangan bawah.

Kepala Desa Kadai mengatakan; "jika masyarakatnya beranggapan terlahir sebagai arung atau keturunan bangsawan pasti akan memisahkan diri dari

\footnotetext{
${ }^{23}$ Andi Hikmat Samad Makkuasseng, Kepala Desa Kadai Kecamatan Mare Kabupaten Bone, Wawancara di kantor Desa Kadai Kecamatan Mare Kabupaten Bone, 15 Juli 2019. Konteks, h. 129.

${ }^{24}$ Muhammad Amin Suma, Keadilan Hukum Waris Islam dalam Pendekatan Teks dan

${ }^{25}$ Ahmad Tholabie Kharlie, Hukum Keluarga Indoenesia, h. 261.
} 
mereka golongan di bawahnya dalam menjalankan kehidupan sehari-hari. Hal ini karena mereka tidak mau mendapat kritik dan saran". ${ }^{26}$

Kepala Desa Sumaling juga mengatakan; "Pokoknya kalau bangsawanki, kedudukanta dalam masyarakat paling tinggi. Semua akan hormat dan segan kepada kita". ${ }^{27}$

Ungkapan Kepala Desa di Mare yakni Kadai dan Sumaling memberikan gambaran bahwa strata sosial memiliki pengaruh dan saling melengkapi dengan adanya keberadaan hukum adat dalam pelaksanaan kehidupan di masyarakat, khususnya masalah waris.

\section{PENUTUP}

Implementasi hukum waris Islam, dengan pembagian harta untuk dilakukan secara kekeluargaan. Bahagian khusus yang disediakan untuk ahli waris yang memeilihara orang tuanya dan harta waris pura bage sebagai kekuasaan mutlak mayit dalam pembagiannya. Penerapan hukum untuk pembagian harta kalālah dilakukan dengan membagi kepada ahli waris secara kekeluargaan tanpa melihat ketentuan hukum Allah. Kendala yang menjadi faktor penghambat implementasi hukum waris Islam hukum adat yang menguasai pelaksanaan pembagian harta waris. Pengetahuan yang belum memadai terkait hukum waris Islam. Implikasinya adalah menyamakan bahagian hak anak laki-laki dan perempuan.

\footnotetext{
${ }^{26}$ Andi Hikmat Samad Makkuasseng, Kepala Desa Kadai Kecamatan Mare Kabupaten Bone, Wawancara di kantor Desa Kadai Kecamatan Mare Kabupaten Bone, 15 Juli 2019.

${ }^{27}$ Andi Salinri, Kepala Desa Sumaling Kecamatan Mare Kabupaten Bone, Wawancara di depan puskesmas Sumaling, 15 Juli 2019.
} 


\section{DAFTAR PUSTAKA}

Abdur Rahman I. Doi, Syariah The Islamic Law Terj.Zaimuddin dan Rusydi Sulaiman, Hudud dan Kewarisan [Syariah II] (Cet. I; Jakarta: RajaGrafindo Persada, 1996).

Ahmad Tholabi Kharlie, Hukum Keluarga Islam (Cet. I; Jakarta Timur: SinarGrafika, 2013).

Suhrawardi K Lubis dan Komis Simanjutak, Hukum Waris Islam [Lengkap dan Praktis] (Cet. I; Jakarta: Sinar Grafika, 1995).

Seperti dikutip oleh Syamsulbahri Salihima, Perkembangan Pemikiran Pembagian Warisan dalm Hukum Islam dan Implementasinya pada Pengadilan Agama (Cet. I; Jakarta: Kencana, 2015).

Otje Salman S, Hukum Waris Islam (Cet. III; Bandung: Refika Aditama, 2010).

Abi' Abdillāh Ibnu Mājah, "Sunan Ibnu Mājah", (Cet.II; Beirūt: DĀR al-Kutub al-'Ilmiyyah, Jilid III, 2009).

Departemen Agama RI, Alquran dan Tafsirnya (Cet. III; Jakarta: Lembaga Percetekan Alquran Departemen Agama, 2009).

Amin Husein Nasution, Hukum Kewarisan [Suatu Analisis Komparatif Pemikiran Mujtahid dan Kompilasi Hukum Islam] (Cet. III; Jakarta: RajaGrafindo Persada, 2014).

Moh. Muhibbin dan Wahid, Hukum Kewarisan Islam (Sebagai Pembaruan Hukum Positif di Indonesia) (Cet.II; Jakarta: Sinar Grafika, 2011)

Ahmad Azhar Basyir, Hukum Waris Islam Edisi Revisi (Cet. XIV; Yogyakarta: UII Press Yogyakarta, 2001).

Andi Jamilah, Masyarakat Desa Sumaling Kecamatan Mare Kabupaten Bone, Wawancara dilakukan di depan rumah, 15 Juli 2019.

Otje Salman, Kesadaran Hukum Masyarakat terhadap Hukum Waris (Cet.II; Bandung: PT.Alumni, 2007).

Andi Hikmat Samad Makkuasseng, Kepala Desa Kadai Kecamatan Mare Kabupaten Bone, Wawancara di kantor Desa Kadai Kecamatan Mare Kabupaten Bone, 15 Juli 2019.

Muhammad Amin Suma, Keadilan Hukum Waris Islam dalam Pendekatan Teks dan Konteks, h. 129.

Andi Salinri, Kepala Desa Sumaling Kecamatan Mare Kabupaten Bone, Wawancara di depan puskesmas Sumaling, 15 Juli 2019. 